\title{
Facial Soft Tissue Augmentation using Autologous Fat Mixed with Stromal Vascular Fraction
}

\author{
Sang Kyun Lee, Deok-Woo Kim, Eun-Sang Dhong, Seung-Ha Park, Eul-Sik Yoon \\ Department of Plastic Surgery, Korea University Anam Hospital, Korea University College of Medicine, Seoul, Korea
}

Background Autologous fat grafting evolved over the twentieth century to become a quick, safe, and reliable method for restoring volume. However, autologous fat grafts have some problems including uncertain viability of the grafted fat and a low rate of graft survival. To overcome the problems associated with autologous fat grafts, we used uncultured adipose tissue-derived stromal cell (stromal vascular fraction, SVF) assisted autologous fat grafting. Thus, the purpose of this study was to evaluate the effect of SVF in a clinical trial.

Methods SVF cells were freshly isolated from half of the aspirated fat and were used in combination with the other half of the aspirated fat during the procedure. Between March 2007 and February 2008, a total of 9 SVF-assisted fat grafts were performed in 9 patients. The patients were followed for 12 weeks after treatment. Data collected at each follow-up visit included clinical examination of the graft site(s), photographs for historical comparison, and information from a patient questionnaire that measured the outcomes from the patient perspective. The photographs were evaluated by medical professionals.

Results Scores of the left facial area grafted with adipose tissue mixed with SVF cells were significantly higher compared with those of the right facial area grafted with adipose tissue without SVF cells. There was no significant adverse effect.

Conclusions The subjective patient satisfaction survey and surgeon survey showed that SVFassisted fat grafting was a surgical procedure with superior results.

Keywords Cell transplants / Tissue grafts / Mesenchymal stem cells / Adipose tissue

\author{
Correspondence: Eul-Sik Yoon \\ Department of Plastic Surgery, Korea \\ University Anam Hospital, Korea \\ University College of Medicine, \\ 73 Inchon-ro, Seongbuk-gu, Seoul \\ 136-705, Korea \\ Tel: $+82-2-920-5368$ \\ Fax: +82-2-922-7437 \\ E-mail: yesanam2@korea.ac.kr
}

Received: 25 May 2012 • Revised: 3 Aug 2012 • Accepted: 3 Aug 2012

pISSN: 2234-6163 • elSSN: 2234-6171 • http://dx.doi.org/10.5999/aps.2012.39.5.534 • Arch Plast Surg 2012;39:534-539

\section{INTRODUCTION}

Fat grafts for restoring soft tissue defects have been used for many decades $[1,2]$, and various methods are currently in use. In particular, the results of studies on restoring fat, cartilage, bone, muscle, and nerve tissue using adipose tissue-derived stem cells (ASC) have been reported [3-7]. However, the advantages and disadvantages of fat grafts are still under debate, and an ideal method has not yet been established. Furthermore, in spite of the various studies suggesting methods for enhancing the sur- vival rate of grafted adipose tissues, no method has been recognized to be ideal.

In a previous study, we reported the long-term follow-up results of facial fat grafts performed using the Coleman procedure, and we confirmed fat grafting to be a reliable procedure [2]. We also confirmed that autologous stromal vascular fraction (SVF) could be effectively used for treating phalangeal bone defects [6].

Based on our previous study results, the effects of SVF on the generation and long-term survival rate of adipose tissue were investigated in the present study by comparing grafts of adipose 
tissue mixed with SVF obtained from adipose tissue and grafts of adipose tissue not mixed with SVF to the facial area of patients.

\section{METHODS}

\section{Patients}

All patients provided written informed consent. Out of the 35 patients who wanted a fat graft during face-lift and facial contouring surgeries in the period from March 2007 to February 2008, 9 patients that could be followed up were selected for the present study. Follow-up was conducted every 2 weeks up to the postoperative 12th week in order to evaluate the results of the fat grafts, and then every month after that up to 11 months postoperatively according to the condition of the patient in order to evaluate complications. The age of the patients ranged from 29 to 68 years with a mean of 43.3 years. The numbers of male and female patients were 3 and 6 , respectively (Table 1 ).

\section{Procedures}

Taking into consideration the individual features of each patient, donor sites were selected mainly from the lower abdomen, hip, and thigh before developing the appropriate design. Sleep anesthesia was induced through intravenous injection of 1.0-2.0 $\mathrm{mg} / \mathrm{kg}$ of ketamine (Huons Co., Seoul, Korea), 0.1-0.2 mg/kg of midazolam (Bukwang Pharm. Co., Seoul, Korea), and 1.5-2.5 $\mathrm{mg} / \mathrm{kg}$ of propofol (Dongkook Co., Seoul, Korea); the heart rate and oxygen saturation were then monitored. A tumescent solution consisting of a mixture of Hartmann's solution (JW Pharm. Co., Seoul, Korea), 0.1\% lidocaine (Huons Co.), and 1:100,000 epinephrine (Daihan Pharm. Co., Seoul, Korea) was injected using a $10 \mathrm{~mL}$ syringe into the fat donor sites.

After waiting for 10 minutes until the tumescent solution penetrated into the tissue, a cannula with a round tip was connected to a $10 \mathrm{~mL}$ Luer-Lok (Becton, Dickinson and Co., Franklin Lakes, NJ, USA) syringe. Using this device, a negative pressure of 1-2 $\mathrm{mL}$ vacuum was then applied to aspirate adipose tissue [8].

\section{Table 1. Age distribution of the patients}

\begin{tabular}{|lcc|}
\hline Patient number & Age & Sex \\
\hline 1 & 62 & $\mathrm{~F}$ \\
2 & 40 & $\mathrm{~F}$ \\
3 & 37 & $\mathrm{M}$ \\
4 & 43 & $\mathrm{M}$ \\
5 & 29 & $\mathrm{~F}$ \\
6 & 53 & $\mathrm{~F}$ \\
7 & 26 & $\mathrm{M}$ \\
8 & 32 & $\mathrm{~F}$ \\
9 & 68 & $\mathrm{~F}$ \\
Average & $43.3 \pm 14.7$ & \\
\hline
\end{tabular}

In order to minimize destruction of adipose tissue, the vacuum space in the $10 \mathrm{~mL}$ syringe was limited to less than $2 \mathrm{~mL}$. The syringe loaded with the aspirated fat tissue was capped so that the syringe was air-tight and kept upright. The adipose tissue was centrifuged at 3,000 rpm for 3 minutes to separate the adipose tissue in the supernatant fluid from the blood cells, tumescent solution, and water in the lower layers, which were subsequently removed [2].

Half of the aspirated adipose tissue was kept in a refrigerator while the remaining half was used for the process of extracting SVF cells. Extracted adipose tissue was rinsed with phosphatebuffered saline to remove blood cells, tumescent solution, and water before treatment with $0.075 \%$ collagenase at $37^{\circ} \mathrm{C}$ for 30 minutes. After that, the collagenase was inactivated using Dulbecco's modified Eagle medium (DMEM, Gibco, Carlsbad, CA, USA), which was added in the same amount as the collagenase. The treated cells were centrifuged at 1,500 rpm for 5 minutes. Supernatant fluid was removed after centrifugation, and only the SVF cells containing ASCs remained. After resuspending the SVF cells in $10 \%$ fetal bovine serum, centrifugation was conducted again before removing the remnants using $100 \mu \mathrm{m}$ nylon filters [9]. SVF cells obtained from the above process were mixed with half of the aspirated adipose tissue before injection, and the remaining adipose tissue was also used for injection.

Adipose tissue with SVF cells, and adipose tissue without SVF cells were loaded into separate $1 \mathrm{~mL}$ syringes, and the syringes were connected with an injection cannula. While moving the cannula back and forth beneath the skin, 0.3 to $0.5 \mathrm{~mL}$ of fat was grafted each time the cannula was moved back. The recipient site was filled with fat from the bottom up during fat grafting. In order to reduce tissue damage, and prevent inflow of fat into the blood vessels, only a Coleman type cannula (Byron Medical Inc., Tucson, AZ, USA), which has a round tip, was used for the fat graft [2].

Fat was grafted multiple times, in a minimum amount each time, to form the facial contour. Tape was attached to the graft sites to fix the grafted fat in position. Adipose tissue mixed with SVF cells was grafted into the left facial area, while adipose tissue without SVF cells was grafted into the right facial area for comparison. The volume of the graft was decided by the surgeon who took into consideration the individual conditions of the patients, but the amount of fat grafted into the right and left side of the face of the same patient were about the same. Fat was grafted into the malar eminence, infraorbital region, and nasolabial fold. No additional graft was conducted after the initial graft.

\section{Results evaluation}

Follow-up and progress evaluation were conducted during out- 
patient visits through clinical observation of the transplantation sites, photographs, patient satisfaction assessment reports, and a questionnaire answered by a plastic surgeon who did not perform the procedure. Evaluation of the areas of the graft including the malar eminence, infraorbital region, and nasolabial fold was performed using a patient satisfaction assessment and a questionnaire filled out by a plastic surgeon. The 5 categories of assessment included in the questionnaire were volume consistency, softness, irregularity, naturality, and overall satisfaction [2]. Each category had an evaluation score between 1 and 10, with a higher score indicating a better outcome (Fig. 1). Evaluation was conducted using photos of the patient to compare the images before surgery and 12 weeks after surgery and noting the scores. The evaluation score of the left facial area grafted with adipose tissue mixed with SVF cells was compared with that of the right facial area grafted with adipose tissue without SVF cells for statistical analysis.

\section{Statistical analysis}

All results were expressed as a median (range, min-max), and the Wilcoxon signed-rank test was used for the statistical processing of the results. Statistical significance was recognized when the P-value was 0.05 or less. The data were analyzed using SPSS ver. 12.0 (SPSS Inc., Chicago, IL, USA) software.

\section{RESULTS}

Results of the patient and plastic surgeon evaluations were analyzed separately. According to the patient evaluation, the evaluation score of the malar eminence of the left facial area grafted with adipose tissue mixed with SVF cells was significantly higher than that of the malar eminence of the right facial area grafted with adipose tissue without SVF cells in all 5 categories of volume consistency, softness, irregularity, naturality, and overall satisfaction. In addition, evaluation scores of the left infraorbital region and nasolabial fold were also significantly higher than

\section{Fig. 1. Questionnaires for the results evaluation}

\begin{tabular}{|c|c|c|c|c|c|c||}
\hline \multirow{2}{*}{ Subjective category } & \multicolumn{2}{|l|}{ Malar eminence } & \multicolumn{2}{l|}{ Infraorbital region } & \multicolumn{2}{l|}{ Nasolabial fold } \\
\cline { 2 - 7 } & Left & Right & Left & Right & Left & Right \\
\hline Volume consistency & & & & & & \\
\hline Softness & & & & & & \\
\hline Irregularity & & & & & & \\
\hline Naturality & & & & & & \\
\hline Overall satisfaction & & & & & & \\
\hline
\end{tabular}

Each category has an evaluation score between 1 and 10, with a higher score indicating a better outcome. those of the right facial area (Tables 2-4).

Moreover, according to the evaluation conducted by the plastic surgeons, scores of the malar eminence, infraorbital region, and nasolabial fold of the left facial area grafted with adipose tissue mixed with SVF cells were significantly higher compared with those of the right facial area grafted with adipose tissue without SVF cells (Tables 5-7).

In both the patient evaluations and surgeon evaluations, the highest evaluation score was given to the nasolabial fold followed by the malar eminence and infraorbital region (Tables 8,9 ). Differences in scores between the patient evaluations and surgeon

Table 2. Surgical outcome on malar eminence as evaluated by the patients

\begin{tabular}{|lccc|}
\hline $\begin{array}{l}\text { Subjective } \\
\text { category }\end{array}$ & $\begin{array}{c}\text { Mean patient } \\
\text { rating (malar } \\
\text { eminence, left) }\end{array}$ & $\begin{array}{c}\text { Mean patient } \\
\text { rating (malar } \\
\text { eminence, right) }\end{array}$ & P-value \\
\hline Volume consistency & $7(7-8)$ & $6(5-7)$ & 0.007 \\
Softness & $7(6-9)$ & $6(4-8)$ & 0.047 \\
Irregularity & $7(6-8)$ & $6(5-7)$ & 0.026 \\
Naturality & $8(6-9)$ & $6(5-7)$ & 0.024 \\
Overall satisfaction & $7(6-8)$ & $6(5-8)$ & 0.043 \\
Total & $36(34-42)$ & $30(27-33)$ & 0.008 \\
\hline a)Wilcoxon signed-rank test was used for the statistical processing of the results.
\end{tabular}

Table 3. Surgical outcome on infraorbital region as evaluated by the patients

\begin{tabular}{|lccc|}
\hline $\begin{array}{l}\text { Subjective } \\
\text { category }\end{array}$ & $\begin{array}{c}\text { Mean patient } \\
\text { rating } \\
\text { (infraorbital } \\
\text { region, left) }\end{array}$ & $\begin{array}{c}\text { Mean patient } \\
\text { rating } \\
\text { (infraorbital } \\
\text { region, right) }\end{array}$ & P-value \\
\hline Volume consistency & $7(6-8)$ & $6(5-7)$ & 0.033 \\
Softness & $7(7-9)$ & $6(5-8)$ & 0.008 \\
Irregularity & $7(5-8)$ & $6(4-7)$ & 0.044 \\
Naturality & $7(6-9)$ & $5(4-7)$ & 0.007 \\
Overall satisfaction & $8(7-9)$ & $6(5-7)$ & 0.010 \\
Total & $36(33-42)$ & $29(25-33)$ & 0.007 \\
\hline a)Wilcoxon signed-rank test was used for the statistical processing of the results.
\end{tabular}

Table 4. Surgical outcome on nasolabial fold as evaluated by the patients

\begin{tabular}{|lccc|}
\hline $\begin{array}{l}\text { Subjective } \\
\text { category }\end{array}$ & $\begin{array}{c}\text { Mean patient } \\
\text { rating } \\
\text { (nasolabial fold, } \\
\text { left) }\end{array}$ & $\begin{array}{c}\text { Mean patient } \\
\text { rating } \\
\text { (nasolabial fold, } \\
\text { right) }\end{array}$ & P-value \\
\hline Volume consistency & $8(6-9)$ & $7(5-8)$ & 0.011 \\
Softness & $8(7-9)$ & $7(5-8)$ & 0.016 \\
Irregularity & $8(6-8)$ & $6(4-7)$ & 0.007 \\
Naturality & $7(7-8)$ & $6(5-7)$ & 0.016 \\
Overall satisfaction & $8(7-9)$ & $7(5-8)$ & 0.011 \\
Total & $39(36-42)$ & $30(27-35)$ & 0.008 \\
\hline a)Wilcoxon signed-rank test was used for the statistical processing of the results.
\end{tabular}


evaluations were negligible and statistically insignificant. In all 5 categories of volume consistency, softness, irregularity, naturality, and overall satisfaction, the area grafted with adipose tissue mixed with SVF cells showed significantly better results compared with those of areas grafted with adipose tissue without cells.

Evaluation was conducted 12 weeks postoperatively. After the initial overcorrection, the appearance of the grafted areas became more natural during the follow-up period, and all of the patients were satisfied with their appearance (Figs. 2, 3).

Table 5. Surgical outcome on malar eminence as evaluated by a separate surgeon

\begin{tabular}{|lccc|}
\hline $\begin{array}{l}\text { Subjective } \\
\text { category }\end{array}$ & $\begin{array}{c}\text { Mean patient } \\
\text { rating (malar } \\
\text { eminence, left) }\end{array}$ & $\begin{array}{c}\text { Mean patient } \\
\text { rating (malar } \\
\text { eminence, right) }\end{array}$ & P-value ${ }^{\text {a) }}$ \\
\hline Volume consistency & $7(6-8)$ & $6(5-7)$ & 0.015 \\
Softness & $7(5-8)$ & $5(4-7)$ & 0.044 \\
Irregularity & $7(6-8)$ & $5(5-7)$ & 0.019 \\
Naturality & $7(6-9)$ & $6(4-7)$ & 0.011 \\
Overall satisfaction & $7(7-8)$ & $6(5-7)$ & 0.014 \\
Total & $36(32-38)$ & $29(25-31)$ & 0.008 \\
\hline a) Wilcoxon signed-rank test was used for the statistical processing of the results. \\
\hline
\end{tabular}

Table 6. Surgical outcome on infraorbital region as evaluated by a separate surgeon

\begin{tabular}{|lccc|}
\hline $\begin{array}{l}\text { Subjective } \\
\text { category }\end{array}$ & $\begin{array}{c}\text { Mean patient } \\
\text { rating } \\
\text { (infraorbital } \\
\text { region, left) }\end{array}$ & $\begin{array}{c}\text { Mean patient } \\
\text { rating } \\
\text { (infraorbital } \\
\text { region, right) }\end{array}$ & P-value ${ }^{\text {a) }}$ \\
\hline Volume consistency & $7(6-9)$ & $6(5-6)$ & 0.010 \\
Softness & $7(6-8)$ & $6(5-7)$ & 0.020 \\
Irregularity & $7(6-7)$ & $6(5-7)$ & 0.035 \\
Naturality & $7(5-8)$ & $5(4-7)$ & 0.037 \\
Overall satisfaction & $7(7-9)$ & $6(5-7)$ & 0.011 \\
Total & $35(32-40)$ & $28(25-32)$ & 0.007 \\
\hline
\end{tabular}

a)Wilcoxon signed-rank test was used for the statistical processing of the results.

\section{DISCUSSION}

Since fat graft was first introduced in 1893 by Neuber, various methods have been suggested [10]. Adipose tissue is easily and repeatedly obtained, and fat graft is a simple and low-risk procedure. Accordingly, fat graft is now one of the most common and widely used procedures in plastic surgery. Because the fat tissue used in these procedures is autologous, no side effects caused by immune responses have been reported, and any part of the body can be a recipient site. However, grafted fat can be absorbed into the body, and the level of absorption is difficult to anticipate. In addition, results can be significantly different from surgeon to surgeon and accordingly, quantitative analysis and evaluation of fat grafts are not easy.

Studies on embryonic stem cells and adult stem cells are active in the field of biotechnology [5]. Embryonic stem cells are ideal stem cells for tissue reconstruction because they can differentiate into various tissues. However, differentiation of embryonic stem cells is difficult to control, and the risk of malignant degeneration is present. Ethical issues are another factor restricting their clinical applications [6]. In contrast, adult stem cells are ob-

Table 7. Surgical outcome on nasolabial fold as evaluated by a separate surgeon

\begin{tabular}{|lccc|}
\hline $\begin{array}{l}\text { Subjective } \\
\text { category }\end{array}$ & $\begin{array}{c}\text { Mean patient } \\
\text { rating } \\
\text { (nasolabial fold, } \\
\text { left) }\end{array}$ & $\begin{array}{c}\text { Mean patient } \\
\text { rating } \\
\text { (nasolabial fold, } \\
\text { right) }\end{array}$ & P-value \\
\hline Volume consistency & $8(7-9)$ & $6(5-8)$ & 0.017 \\
Softness & $8(6-9)$ & $6(4-8)$ & 0.014 \\
Irregularity & $7(6-8)$ & $6(5-6)$ & 0.011 \\
Naturality & $7(6-8)$ & $5(4-6)$ & 0.027 \\
Overall satisfaction & $8(7-9)$ & $6(5-7)$ & 0.011 \\
Total & $37(36-41)$ & $30(24-34)$ & 0.008 \\
\hline a)Wilcoxon signed-rank test was used for the statistical processing of the results.
\end{tabular}

Table 8. Surgical outcome on nasolabial fold versus malar eminence and infraorbital region as evaluated by the patients

\begin{tabular}{|c|c|c|c|c|c|c|}
\hline & $\begin{array}{l}\text { Mean patient } \\
\text { rating (nasolabial } \\
\text { fold, left) }\end{array}$ & $\begin{array}{l}\text { Mean patient } \\
\text { rating (malar } \\
\text { eminence, left) }\end{array}$ & P-value ${ }^{a}$ & $\begin{array}{c}\text { Mean patient } \\
\text { rating (nasolabial } \\
\text { fold, left) }\end{array}$ & $\begin{array}{l}\text { Mean patient } \\
\text { rating (infraorbital } \\
\text { region, left) }\end{array}$ & P-value ${ }^{a)}$ \\
\hline Total & $39(36-42)$ & $36(34-42)$ & 0.041 & 39 (36-42) & 36 (33-42) & 0.048 \\
\hline
\end{tabular}

Table 9. Surgical outcome on nasolabial fold versus malar eminence and infraorbital region as evaluated by a separate surgeon

\begin{tabular}{|c|c|c|c|c|c|c|}
\hline & $\begin{array}{l}\text { Mean patient } \\
\text { rating (nasolabial } \\
\text { fold, left) }\end{array}$ & $\begin{array}{l}\text { Mean patient } \\
\text { rating (malar } \\
\text { eminence, left) }\end{array}$ & P-value ${ }^{a)}$ & $\begin{array}{l}\text { Mean patient } \\
\text { rating (nasolabial } \\
\text { fold, left) }\end{array}$ & $\begin{array}{l}\text { Mean patient } \\
\text { rating (infraorbital } \\
\text { region, left) }\end{array}$ & P-value ${ }^{a)}$ \\
\hline Total & $37(36-41)$ & $36(32-38)$ & 0.042 & $37(36-41)$ & $35(32-40)$ & 0.043 \\
\hline
\end{tabular}




\section{Fig. 2. Fat graft with SVF cells (case 1)}

$(A, B)$ Improved nasolabial fold, malar eminence, and infraorbital region after a fat graft with SVF cells (left face) or a fat graft without SVF cells (right face). The left face showed the better result. (A) Preoperative view. (B) Postoperative view at 12 weeks. (C, D) Facial bone computed tomography. Improved nasolabial fold region after a fat graft with SVF cells (left face) or a fat graft without SVF cells (right face). (C) Preoperative view. (D) Postoperative view at 12 weeks. SVF, stromal vascular fraction.
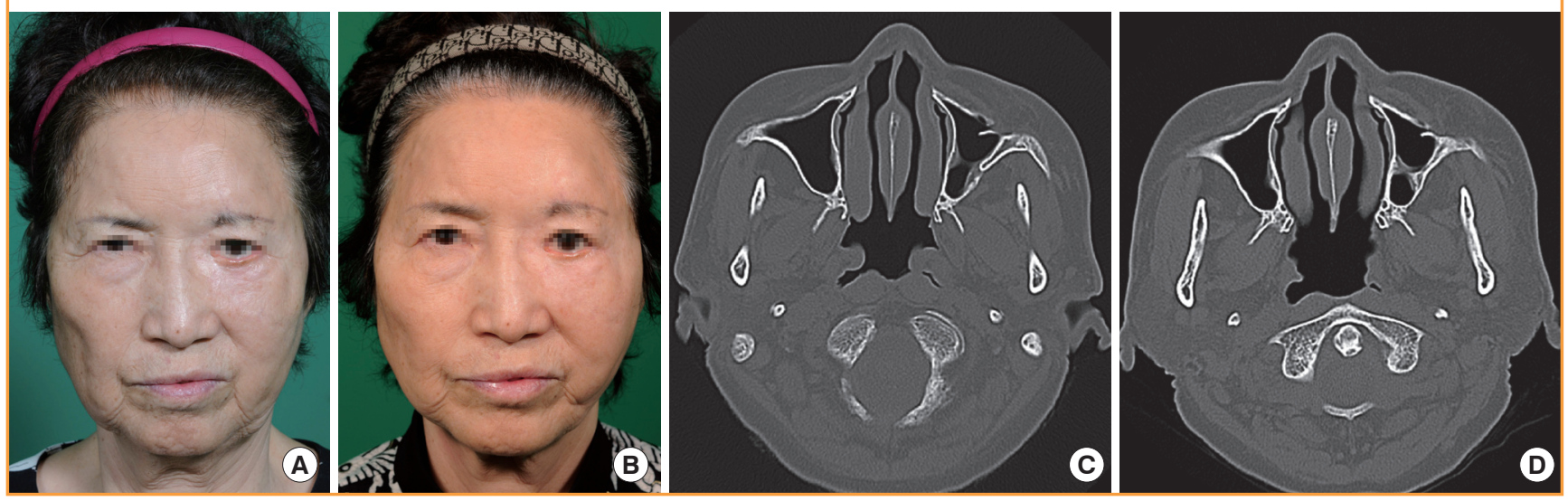

\section{Fig. 3. Fat graft with SVF cells (case 2)}

Improved nasolabial fold, malar eminence, and infraorbital region after a fat graft with SVF cells (left face) or a fat graft without SVF cells (right face). The left face showed the better result. (A) Preoperative view. (B) Postoperative view at 12 weeks. SVF, stromal vascular fraction.
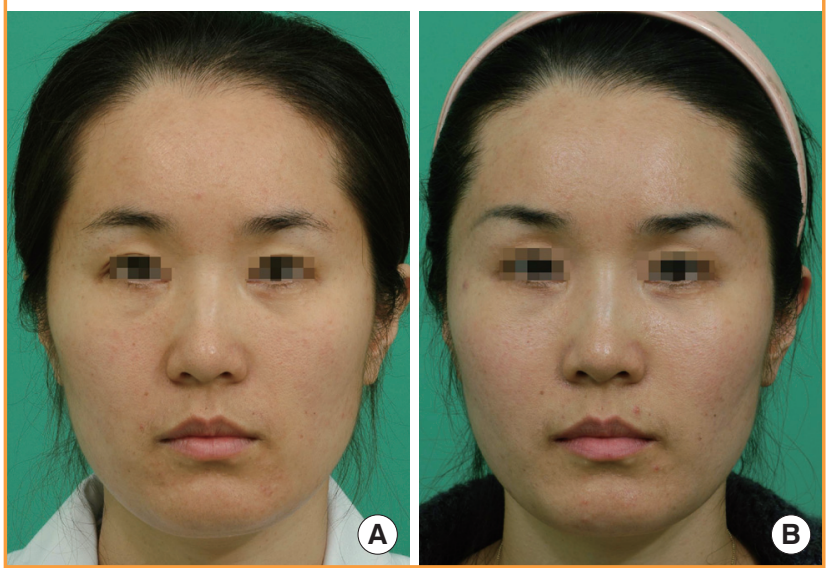

tained from already differentiated tissues, and are free from ethical controversy. Among adult stem cells, adipose stem cells are actively studied because they are easily obtainable. According to an in vitro experiment conducted by Zuk et al. [3], adipose stem cells can differentiate into cells of fat, cartilage, muscle, and bone. In practice, the clinical application of adipose stem cells in a graft is not easy because cell culture facilities that gain the approval of the Korea Food and Drug Administration need to be used. Due to these limitations, recent studies have focused on SVF cells that are obtained when adipose tissue is centrifuged without the use of cultivation. Leblanc et al. [11] reported that SVF cells obtained from adipose tissue increased blood flow in the coronary artery after the development of myocardial infarction. Lendeckel et al. [12] reported cases of successful bone reconstruction using fibrin glue and SVF cells obtained from adipose tissue, which were grafted into the area of the cranial defect.

In the present study, we tried to delay or prevent absorption of fat after grafting by mixing SVF cells with adipose tissue. At postoperative 12 weeks, the patient and doctor surveys confirmed that the results of grafts with adipose tissue mixed with SVF cells were better than those grafted with adipose tissue without SVF cells in all 5 categories of volume consistency, softness, irregularity, naturality, and overall satisfaction. As suggested by multiple studies $[11,12]$, SVF cells have been considered to facilitate the growth of surrounding tissues. In the present study, this function of SVF cells was observed. However, the mechanism of SVF cells facilitating the growth of surrounding fat cells is not clearly understood. Additional studies investigating this issue are expected in the future.

According to the present study, the highest evaluation score after a fat graft mixed with SVF cells was assigned to the nasolabial fold followed by the malar eminence and infraorbital region (Tables 8, 9). In our previous study [2], the lowest satisfaction score after graft was assigned to the nasolabial fold area. The reason for the different results between the previous and the present study is considered to be due to the SVF cells used in the present study having a remarkable effect in the area of nasolabial fold, which usually has low satisfaction scores due to the deepness of the fold.

Quantitative analysis or measurement of the adipose tissue that remains after a fat graft is difficult to perform in practice. Therefore, the effects of the fat grafts were evaluated through surveys using the clinical photos. However, this method is limited by the subjective nature of the evaluation carried out by the patients or surgeons. In the future, an objective and quantitative method of 
measuring the fat amount should be developed to calculate the survival rate of SVF cells that are mixed with adipose tissue.

In order to establish a control group, the right side of the face of the patients was grafted with adipose tissue without SVF cells. Consequently, bias was minimized in the present study. Even though this method was used with the permission of the patients, there was a risk of causing an imbalance in the appearance of the right and left side of the face in the patients. For this reason, only 9 patients were enrolled in the present study. A larger number of patients, and a more accurately established control group than the present study may be necessary to obtain more reliable data on the effects of SVF cells on the survival rate of fat cells.

Moreover, there were some limitations to the present study. First, facial bone computed tomography was conducted only at 12 weeks postoperatively. However, it was not conducted immediately after the fat grafts were performed. If we conduct facial bone computed tomography immediately after the operation and at 12 weeks postoperatively, it may measure the absorption rate of fat cells. Second, only 9 patients were enrolled in this study and the follow-up period for the evaluation results was 12 weeks postoperatively. If the number of patients and the followup period were increased, it could verify the effects of SVF cells on the survival rate of fat cells.

The positive effects of SVF cells on the generation and longterm survival rate of adipose tissue were confirmed in the present study. In particular, the effects of SVF cells were more evident in the area of deep wrinkles in the face than in other areas. In conclusion, fat grafts using SVF cells may enhance the survival rate of fat cells and the effects of fat grafts.

\section{REFERENCES}

1. Illouz YG. The fat cell "graft": a new technique to fill depressions. Plast Reconstr Surg 1986;78:122-3.

2. Kim SB, Kim DW, Yoon ES. Facial fat injection: long-term follow-up results. J Korean Soc Aesthetic Plast Surg 2010; 16:35-40.

3. Zuk PA, Zhu M, Mizuno H, et al. Multilineage cells from human adipose tissue: implications for cell-based therapies. Tissue Eng 2001;7:211-28.

4. Dhar S, Yoon ES, Kachgal S, et al. Long-term maintenance of neuronally differentiated human adipose tissue-derived stem cells. Tissue Eng 2007;13:2625-32.

5. Yoon E, Dhar S, Chun DE, et al. In vivo osteogenic potential of human adipose-derived stem cells/poly lactide-co-glycolic acid constructs for bone regeneration in a rat critical-sized calvarial defect model. Tissue Eng 2007;13:619-27.

6. Jeong T, Ji YH, Kim DW, et al. Treatment of phalageal bone defect using autologous stromal vascular fraction from lipoaspirated tissue. J Korean Soc Plast Reconstr Surg 2011; 38:438-44.

7. Poloni A, Maurizi G, Leoni P, et al. Human dedifferentiated adipocytes show similar properties to bone marrow-derived mesenchymal stem cells. Stem Cells 2012;30:965-74.

8. Coleman SR. Hand rejuvenation with structural fat grafting. Plast Reconstr Surg 2002;110:1731-44.

9. Tabit CJ, Slack GC, Fan K, et al. Fat grafting versus adiposederived stem cell therapy: distinguishing indications, techniques, and outcomes. Aesthetic Plast Surg 2012;36:704-13.

10. Ersek RA, Chang P, Salisbury MA. Lipo layering of autologous fat: an improved technique with promising results. Plast Reconstr Surg 1998;101:820-6.

11. Leblanc AJ, Touroo JS, Hoying JB, et al. Adipose stromal vascular fraction cell construct sustains coronary microvascular function after acute myocardial infarction. Am J Physiol Heart Circ Physiol 2012;302:H973-82.

12. Lendeckel S, Jodicke A, Christophis P, et al. Autologous stem cells (adipose) and fibrin glue used to treat widespread traumatic calvarial defects: case report. J Craniomaxillofac Surg 2004;32:370-3. 